\title{
The Synthesis and Biological Activity of 1-Alkyl-4-(3-azacyclobenzoyl)-5- hydroxypyrazole Herbicides
}

\author{
Zoltan Benko*, Sharon Shinkle, John Van Heertum, Johnny Jackson, Jeffery McQuiston, \\ Jeffery Webster, James Turner, Monte Weimer, and Eileen Paterson
}

\begin{abstract}
The benzoylpyrazoles belong to a class of herbicides that inhibit the enzyme 4-hydroxyphenylpyruvate dioxygenase (HPPD). This mode of action is characterized by bleaching due to the disruption of plastoquinone and $\alpha$-tocopherol biosynthesis. Early studies indicated that the $C(3)$ position of benzoylpyrazoles can accommodate a wide range of functionality. This paper describes synthetic efforts to improve cool season grass weed activity and wheat selectivity by incorporating cyclic moieties attached through nitrogen at this position. The aza substituents were generally installed by nucleophilic aromatic substitution, however, an efficient four-step method was developed for constructing substituted morpholino moieties directly on pre-formed benzoylpyrazoles. The structure-activity relationships revealed that certain piperidino moieties provided good activity on wild oat, while exhibiting selectivity toward wheat. They also showed that excellent levels of activity on wild oat and blackgrass can be achieved with morpholino substituents.
\end{abstract}

Keywords: Benzoylpyrazoles · Herbicide $\cdot$ Hydroxyphenylpyruvate dioxygenase inhibitors · Morpholines · Piperidines

\section{Introduction}

1-Alkyl-4-benzoyl-5-hydroxypyrazoles are highly active novel herbicides that are characterized by an appropriately functionalized benzoyl group attached to an acidic hydroxypyrazole (Fig. 1). These materials are herbicidal because they inhibit the enzyme hydroxyphenylpyruvate dioxygenase (HPPD) in the quinone biosynthesis pathway [1]. Inhibition of this step interrupts the synthesis of plastoquinones and $\alpha$-tocopherol, which makes the plant unable to protect itself from photo-oxidation. The unmistakable bleaching symptomology, followed by plant death, is characteristic of this mode of action. Other herbicidal chemistries are known to operate at this site as well, most notably the benzoylcyclohexanediones [2] and the benzoylisoxazoles [3].

\footnotetext{
Correspondence: Dr. Z. Benko

Discovery Research

Dow AgroSciences

9330 Zionsville Road

Indianapolis, IN 46268, USA

Tel.: + 13173373068

Fax: + 13173373215

E-Mail: zlbenko@dow.com
}

Interest in these benzoylpyrazoles stems from the broad spectrum activity observed when they are applied pre- or post emergently on broadleaves and grasses and because they are mobile in both plants and soil. Research at Dow AgroSciences and elsewhere [4] in the late 1980s and early 1990s led to a basic understanding of the structure-activity relationships (SAR) of the benzoylpyrazoles (Fig. 1). Small alkyl substituents on the pyrazole were preferred and the best compounds generally had a $\mathrm{Cl}$ or Me group at the $\mathrm{C}(2)$-position and a $\mathrm{SO}_{2} \mathrm{Me}$ in the (C)4-position of the benzene ring. In contrast to the rest of the molecule, however, the $\mathrm{C}(3)$ position was able to ac-

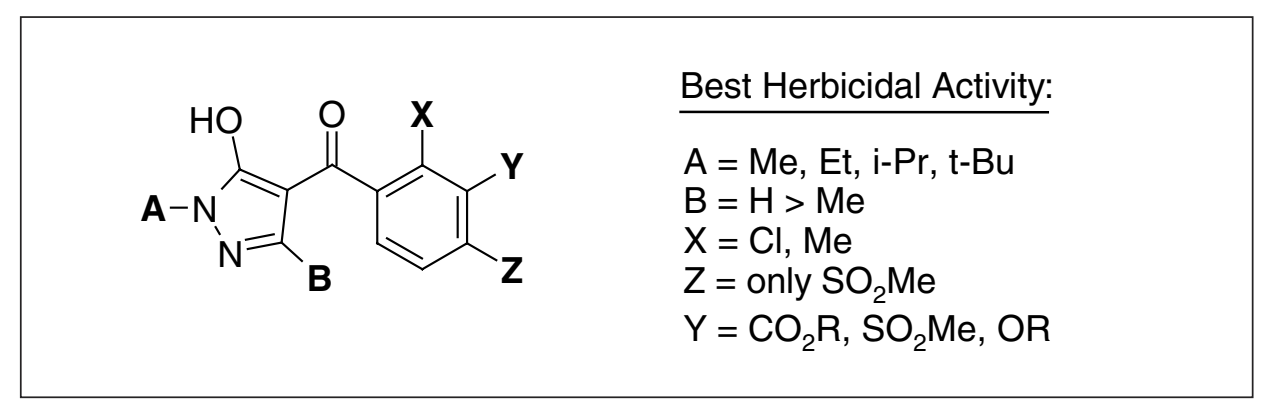

Fig.1. Early structure-activity relationships of benzoylpyrazole herbicides established by Dow AgroSciences and others

commodate many diverse substituents. Sulfones and alkoxycarbonyls were particularly good, as were certain alkoxy substituents. Naturally, we wondered whether nitrogen could replace the electronegative oxygen and provide bioisosteric substituents.

Synthesis of the $3-\mathrm{NMe}_{2}$ substituted analog (Table 1, entry 1) demonstrated that it was possible to utilize a nitrogen at this location and retain herbicidal activity. A general investigation of the area was therefore undertaken [5]. Of primary interest to us, however, was the grass activity inherent in these molecules. The $\mathrm{MeOCH}_{2} \mathrm{CH}_{2} \mathrm{NH}$ group (entry 2) was found to be quite active

Best Herbicidal Activity:

Me, Et, i-Pr, t-Bu

$\mathrm{B}=\mathrm{H}>\mathrm{Me}$

$\mathrm{Z}=$ only $\mathrm{SO}_{2} \mathrm{Me}$

$\mathrm{Y}=\mathrm{CO}_{2} \mathrm{R}, \mathrm{SO}_{2} \mathrm{Me}, \mathrm{OR}$ 
on broadleaves and warm season grasses, but it was unremarkable on the cool season grass weeds wild oat (AVEFA) and blackgrass (ALOMY). Wild oat and blackgrass are considered to be the most important grass weeds to control in wheat (TRZAS) crops. It was not until this 2-methoxy-ethylamino substituent was 'tied back' into a ring, that there was a dramatic increase in efficacy against these key species (entry 3). We therefore turned our attention to exploring this unique subclass of the benzoylpyrazoles. This paper focuses exclusively on the synthesis of analogs in which cyclic amines have been incorporated at C(3) of the benzoyl ring and the resulting biological activity.

\section{Synthesis}

We first synthesized [5] these aminesubstituted materials by taking advantage of the inherent regioselectivity of nucleophilic aromatic substitution on our 2,3,4trisubstituted benzoic acid starting materials 1 (Scheme 1). The C(3) chlorine is the most labile under the basic conditions of the reaction, because the sulfone is a much more powerful ortho director than the carboxylate. The functionalized benzoic acid 2 was then coupled with a 1-alkyl-5hydroxypyrazole to give a mixture of the corresponding ester and amide. This mixture was subsequently rearranged to the $\mathrm{C}$ acylated product $\mathbf{4}$ with a catalytic amount of cyanide.

To improve the efficiency of analog synthesis, we considered performing the nucleophilic substitution later in the sequence, directly on a benzoylpyrazole 3 (Scheme 1). We reasoned that a deprotonated hydroxypyrazole moiety was not unlike a carboxylate with respect to activation of the aromatic ring. This approach worked well and was general, although hindered amines tended to give lower yields [6]. Increased heat or the use of the corresponding 3 -fluoro version of $\mathbf{1}$ or $\mathbf{3}$ could be used to overcome this problem. A number of commercially available cyclic amines were utilized directly in this sequence, although some of the piperidines needed minor modifications [7].

The high level of activity obtained with the morpholine ring was particularly intriguing, but investigation was hindered by the paucity of commercially available morpholines. Even more troubling, however, was the generally low yielding and experimentally difficult methods available in the literature for the synthesis of substituted morpholines. This situation, and our recent success at manipulating advanced ben-

Table 1. SAR comparison of ring size and heteroatoms

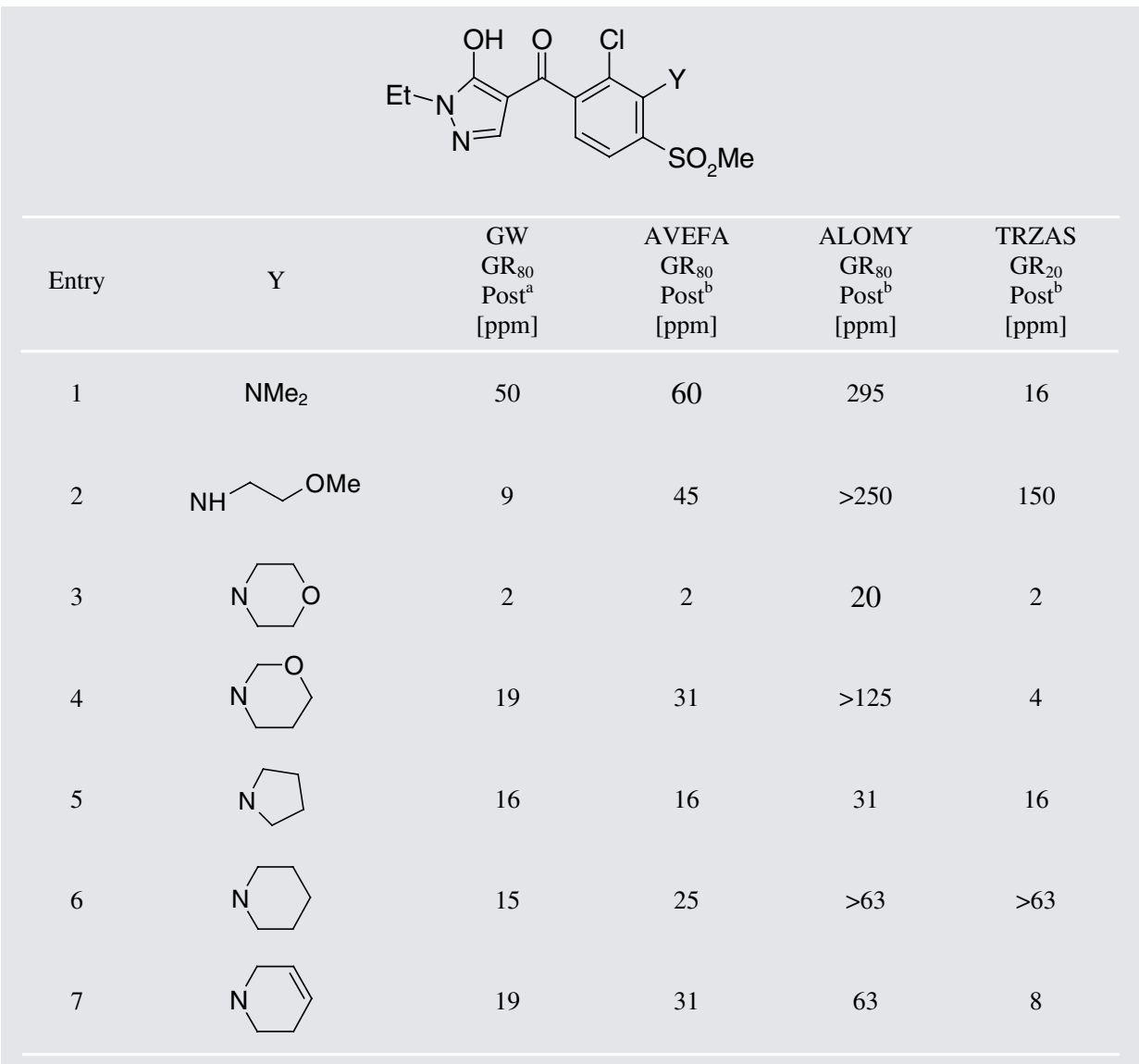

aThe concentration of active ingredient that provides an average growth reduction of $80 \%$ compared to untreated controls when sprayed post emergently on the following grass species: Alopecurus mysuroides (ALOMY), Avena fatua (AVEFA), Digitaria sanguinalis (DIGSA), Echinochloa crus-galli (ECHCG), Setaria faberi (SETFA), Sorghum bicolor (SORBI). ${ }^{\text {b} T h e ~ c o n c e n t r a t i o n ~ o f ~ a c-~}$ tive ingredient that provides the indicated percent growth reduction compared to an untreated control when sprayed post emergently on the listed species. The last column is the wheat crop Triticum aestivum (TRZAS). 'Mixture of cis and trans.

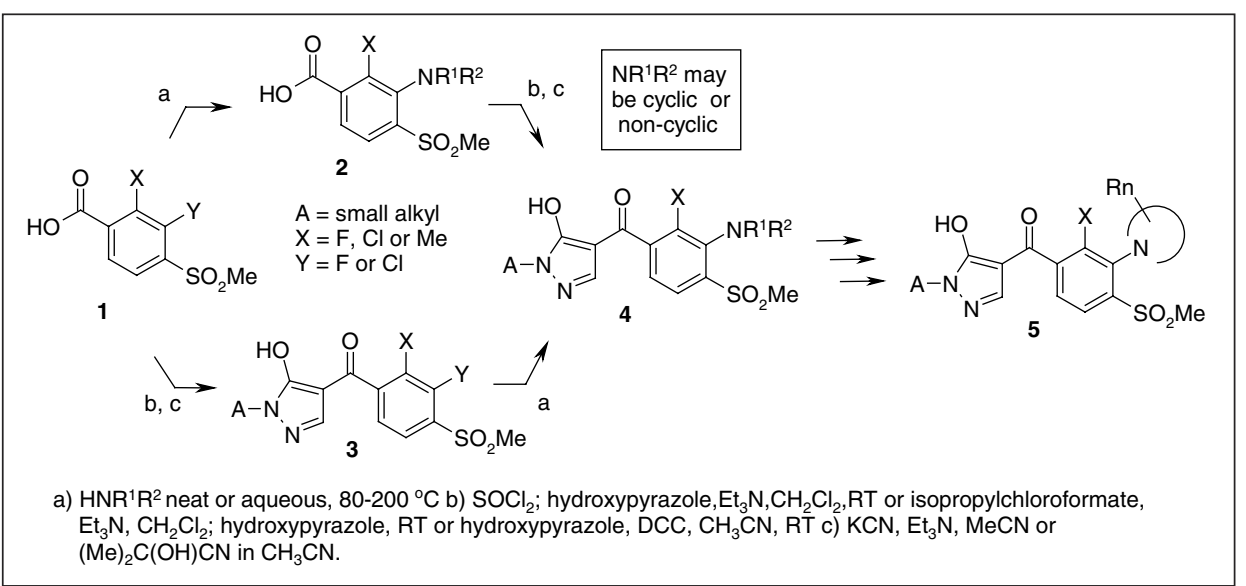

Scheme 1. General synthetic route to 3-(azacyclo)benzoylpyrazoles

zoylpyrazole intermediates, prompted us to consider an in situ approach to the problem (Scheme 2). Typical literature procedures involved the use of protected ethanolamines. It occurred to us, that if we used the benzoylpyrazole itself as a protecting group, we would be working with organic soluble intermediates and no deprotection step would be required. In fact, from earlier work, we already knew that displacement with ethanolamine was facile. The first step starting from 6 then, was to install a substituted ethanolamine, many of which were commercially available or easily synthesized. Under the reaction conditions, the water soluble imine of the ketone was also formed, but this intermediate was readily hydrolyzed in a separate step before isolation of the product 7 . The second step was a cyclization to the lactone 8 achieved by heating 7 with glyoxal [8]. A selective reduction to the lactol 9 [9] was the third step, 
in which the lactone was reduced with diisobutyl aluminum hydride in the presence of the hydroxypyrazole. An extra equivalent of this reagent was necessary for the initial deprotonation. The propensity of benzoylpyrazoles to chelate certain metal ions (iron is best known, but also aluminum and copper) made a strong acidic work-up necessary. If this was not done, it was actually possible to isolate the tribenzoylpyrazolate aluminum salt by column chromatography! The fourth and final step was to replace the hydroxyl of the lactol $\mathbf{9}$ with a variety of nucleophiles or simply reduce it with triethylsilane to obtain the final target 10. For simple alcohols, $\mathrm{HCl}$ was a sufficient catalyst, but more complex alcohols, as well as methylmercaptide and cyanide, required $\mathrm{BF}_{3} \cdot \mathrm{Et}_{2} \mathrm{O}$.

1,3 Oxazine analogs were synthesized via the corresponding 3-amino-1-propanol intermediate by cyclization with formaldehyde or phosgene. Attempts at the synthesis of 5- and 7-membered oxazocycles were unsuccessful [10].

\section{Biological Activity}

The outstanding activity of the morpholino substituted benzoylpyrazole prompted us to investigate a number of other cyclic amines (Table 1). We found that morpholine was the best, but pyrrolidine and piperidine (entry 5 and 6) still showed respectable activity on wild oat coupled with a modest amount of wheat selectivity. The 1,2,5,6terahydropyridine and 1,3-oxazine analogs (entry 4 and 7) also showed activity on wild oat, but with no hint of safety toward wheat. Thiomorpholine, 4-methyl- and 4-acetylpiperazine, 2-oxo-1,3-oxazine (cyclic carbamate) and homopiperidine (7-membered ring) were all inactive at these rates.

Because very few substituted pyrrolidines or morpholines were commercially available, our research program first focused on piperidines, with the intent of improving wild oat activity and wheat selectivity (Table 2). A series of methyl substituted piperidines revealed that certain 3-methyl substituted compounds (entry 3 and 6) retained wild oat activity and the wheat selectivity. Taken together (entry 1 , 3,4 , and 6), the results are consistent with the hypothesis that wheat selectivity depends, at least partially, on metabolism at the $\mathrm{C}(4)$ of the piperidine ring. Unfortunately, all other piperidine substituents were not selective toward wheat, although 3-Cl, 3-MeO and 3-EtO (entry 7, 10, and 11) were active on wild oat.

Our intent with respect to the highly active morpholine ring, was to incorporate a

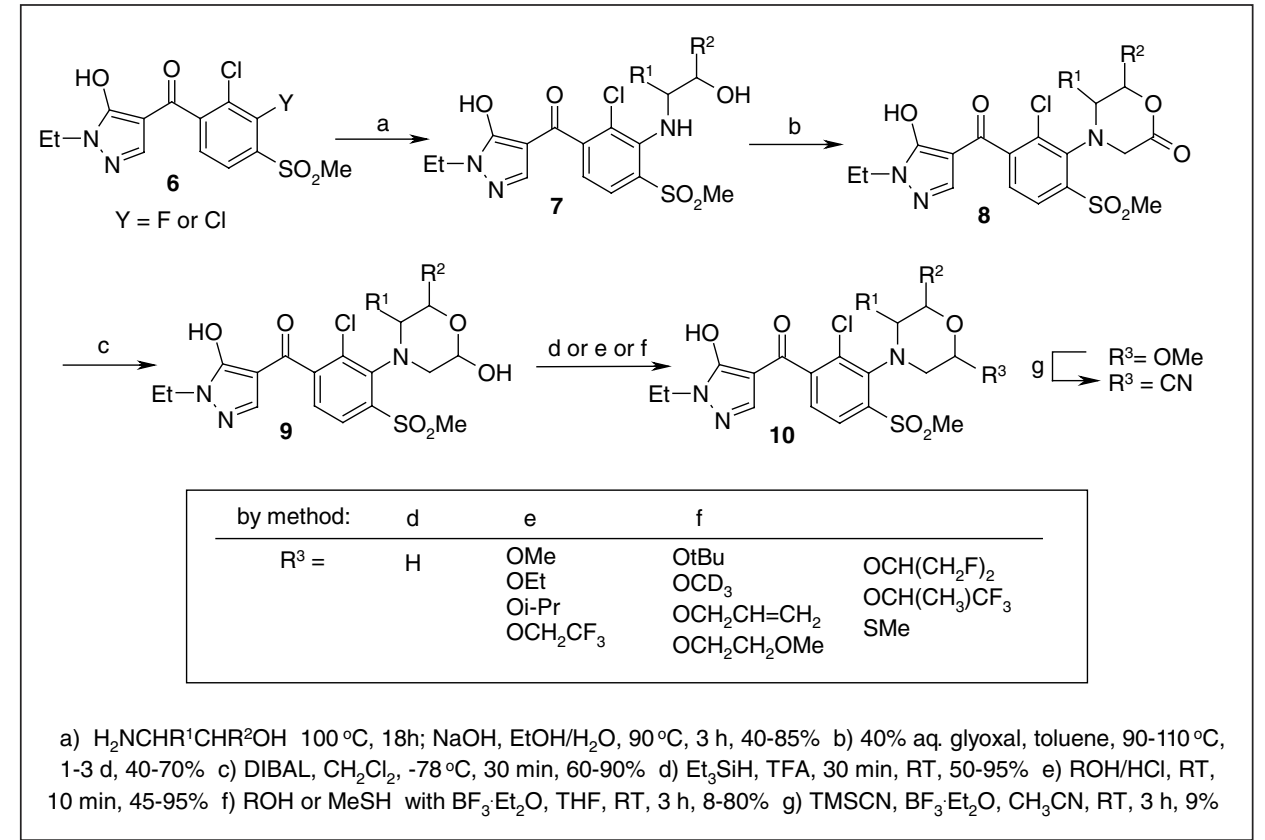

Scheme 2. Synthesis of substituted 3-morpholinobenzoylpyrazoles

Table 2. SAR comparison of substituted piperidine substituents

\begin{tabular}{|c|c|c|c|c|c|}
\hline Entry & $\mathrm{R}_{\mathrm{n}}$ & $\begin{array}{c}\mathrm{GW} \\
\mathrm{GR}_{80} \\
\mathrm{Post}^{\mathrm{a}} \\
{[\mathrm{ppm}]}\end{array}$ & $\begin{array}{c}\text { AVEFA } \\
\text { GR }_{80} \\
\text { Post }^{\mathrm{b}} \\
{[\mathrm{ppm}]}\end{array}$ & $\begin{array}{c}\text { ALOMY } \\
\text { GR }_{80} \\
\text { Post }^{\mathrm{b}} \\
{[\mathrm{ppm}]}\end{array}$ & $\begin{array}{c}\text { TRZAS } \\
\mathrm{GR}_{20} \\
\mathrm{Post}^{\mathrm{b}} \\
{[\mathrm{ppm}]}\end{array}$ \\
\hline 1 & $\mathrm{H}$ & 15 & 25 & $>63$ & $>63$ \\
\hline 2 & $2-\mathrm{Me}$ & 64 & $>125$ & 125 & 12 \\
\hline 3 & $3-\mathrm{Me}$ & 49 & 63 & 250 & 100 \\
\hline 4 & 4-Me & 35 & 55 & $>63$ & 16 \\
\hline 5 & 3,3-diMe & 250 & $>250$ & $>250$ & $>250$ \\
\hline 6 & 3,5-diMe $\mathrm{e}^{\mathrm{c}}$ & 56 & 25 & $>250$ & 63 \\
\hline 7 & $3-\mathrm{Cl}$ & 23 & 25 & $>250$ & 4 \\
\hline 8 & $3-\mathrm{OH}$ & 81 & 50 & 250 & 31 \\
\hline 9 & $3-(=0)$ & 197 & $>250$ & $>250$ & $>250$ \\
\hline 10 & 3-MeO & 51 & 14 & 240 & 4 \\
\hline 11 & 3 -EtO & 60 & 31 & $>250$ & 10 \\
\hline 12 & $3-\mathrm{CO}_{2} \mathrm{Et}$ & 231 & $>250$ & $>250$ & 20 \\
\hline 13 & $4-(=\mathrm{O})$ & 125 & $>125$ & $>125$ & 125 \\
\hline 14 & 4-MeO & 88 & 85 & $>250$ & 45 \\
\hline
\end{tabular}

${ }^{\text {aT }}$ The concentration of active ingredient that provides an average growth reduction of $80 \%$ compared to untreated controls when sprayed post emergently on the following grass species: ALOMY, AVEFA, DIGSA, ECHCG, SETFA, SORBI. ${ }^{\mathrm{b}}$ The concentration of active ingredient that provides the indicated percent growth reduction compared to an untreated control when sprayed post emergently on the listed species. ${ }^{\mathrm{C}}$ Mixture of cis and trans.

substituent that would allow selective metabolism to occur in wheat. The biological data (Table 3) revealed that excellent activity on both wild oat and blackgrass could be retained with small alkyl substituents (entry $1-7)$. Reasonable activity on wild oat was also obtained with a 2-MeO group (entry 11 ), but this was lost very quickly with increasing size of the alkoxy substituent. (entry 13-15). A modest recovery in this trend was made with the $\mathrm{CF}_{3} \mathrm{CH}_{2} \mathrm{O}$ group (entry
16) which was attributed to the ability of the fluorines to destabilize the incipient free radical typically formed during metabolism of an alkoxy group [11]. It was also interesting to note that the overall loss in activity engendered by a 2-MeO group was mitigated by the presence of a 6-Et substituent (entry 11, 25, and 26). Stereochemical effects across the morpholine ring were insignificant (entry 25 and 26, 27 and 28, 29 and 30), though a significant effect was 
noted between a pair of diastereomeric branched fluoroalkoxy substituents (entry 18 and 19). In the end, however, no selectivity toward wheat was observed in any of the analogs.

\section{The Most Effective \\ 3-Azacyclobenzoylpyrazoles}

To highlight the biological effect of incorporating cyclic amines at the $\mathrm{C}(3)$ position of benzoylpyrazoles in this paper, substitution at all other positions was held constant. Our overall research program, however, was directed at optimizing these novel substituents in concert with the rest of the molecule (Table 4). The most effective molecule with respect to overall activity on the key cool season grass weeds wild oat and blackgrass (entry 1), was in fact an unsubstituted morpholino analog. The best wild oat compound with the greatest selectivity toward wheat (entry 2), however, contained a 3-methylpiperidino moiety.

Table 3. SAR comparison of substituted morpholino substituents

Table 4. Optimized 3-azacyclobenzoylpyrazoles

\begin{tabular}{|c|c|c|c|c|c|}
\hline \multirow[b]{2}{*}{ Entry } & \multirow[b]{2}{*}{$\mathrm{R}_{\mathrm{n}}$} & \multicolumn{2}{|r|}{$\int_{\mathrm{N}-\gamma_{2} \mathrm{Me}}^{2} \mathrm{X}_{\mathrm{Rr}}$} & \multirow[b]{2}{*}{$\begin{array}{c}\text { ALOMY } \\
\text { GR }_{80} \\
\text { Post }^{\mathrm{b}} \\
{[\mathrm{ppm}]}\end{array}$} & \multirow[b]{2}{*}{$\begin{array}{c}\text { TRZAS } \\
\mathrm{GR}_{20} \\
\text { Post }^{\mathrm{t}} \\
{[\mathrm{ppm}]}\end{array}$} \\
\hline & & $\begin{array}{c}\mathrm{GW} \\
\mathrm{GR}_{80} \\
\text { Post }^{\mathrm{a}} \\
{[\mathrm{ppm}]}\end{array}$ & $\begin{array}{c}\text { AVEFA } \\
\mathrm{GR}_{80} \\
\text { Post }^{\mathrm{b}} \\
{[\mathrm{ppm}]}\end{array}$ & & \\
\hline 1 & $\mathrm{H}$ & 2 & 2 & 20 & 2 \\
\hline 2 & $3-\mathrm{Me}$ & 7 & 3 & 31 & 2 \\
\hline 3 & 3-i-Pr & 7 & 10 & 31 & $<4$ \\
\hline 4 & $2-\mathrm{Me}$ & 6 & 3 & 25 & 1 \\
\hline 5 & 2-Et & 5 & 7 & 14 & 2 \\
\hline 6 & 2-i-Pr & 10 & 63 & 31 & 4 \\
\hline 7 & 2,6-diMe $\mathrm{e}^{\mathrm{c}}$ & 4 & 4 & 12 & $<4$ \\
\hline 8 & $2-\mathrm{Ph}$ & 51 & 8 & 250 & 5 \\
\hline 9 & $2=(0)$ & $>250$ & $>250$ & $>250$ & $>250$ \\
\hline 10 & $2-\mathrm{OH}$ & $>62$ & $>62$ & $>62$ & $>62$ \\
\hline 11 & $2-\mathrm{MeO}$ & 63 & 31 & 50 & 12 \\
\hline 12 & $2-\mathrm{CD}_{3} \mathrm{O}$ & 6 & 8 & 78 & 1 \\
\hline 13 & 2-EtO & $>125$ & $>125$ & $>125$ & $>125$ \\
\hline 14 & 2-i-PrO & $>125$ & $>125$ & $>125$ & $>125$ \\
\hline 15 & 2-t-BuO & $>63$ & $>63$ & $>63$ & $>63$ \\
\hline 16 & $2-\mathrm{CF}_{3} \mathrm{CH}_{2} \mathrm{O}$ & 45 & 50 & 125 & 4 \\
\hline 17 & 2- $\left(\mathrm{CH}_{2} \mathrm{~F}\right)_{2} \mathrm{CHO}$ & 70 & 103 & 200 & 5 \\
\hline 18 & $2-\mathrm{CF}_{3}(\mathrm{Me}) \mathrm{CHO}(1)^{\mathrm{d}}$ & 40 & 54 & 100 & 5 \\
\hline 19 & $2-\mathrm{CF}_{3}(\mathrm{Me}) \mathrm{CHO}(2)^{\mathrm{d}}$ & 4 & 3 & 31 & $<2$ \\
\hline 20 & 2- $\mathrm{MeOCH}_{2} \mathrm{CH}_{2} \mathrm{O}$ & 58 & 125 & $>250$ & 31 \\
\hline 21 & 2- $\mathrm{CH}_{2}=\mathrm{CHCH}_{2} \mathrm{O}$ & 199 & $>250$ & $>250$ & 31 \\
\hline 22 & 2-MeS & 1258 & $>250$ & $>250$ & 10 \\
\hline 23 & $2-\mathrm{CN}$ & 33 & 31 & 125 & 12 \\
\hline 24 & $2-\mathrm{MeO}, 5-\mathrm{Me}^{\mathrm{c}}$ & 19 & 20 & 50 & 4 \\
\hline 25 & cis-2-MeO, 6-Et & 6 & 8 & 8 & 4 \\
\hline 26 & trans-2-MeO, 6-Et & 16 & 12 & 14 & 4 \\
\hline 27 & $c i s-2-\mathrm{MeO}, 6-\mathrm{i}-\mathrm{Pr}$ & 26 & 30 & 100 & $<16$ \\
\hline 28 & trans-2-MeO, 6-i-Pr & 98 & 30 & 100 & $<16$ \\
\hline 29 & cis-2-MeO, 6-Ph & 16 & 25 & 63 & 3 \\
\hline 30 & trans-2-MeO, 6-Ph & 30 & 14 & 63 & 10 \\
\hline $\begin{array}{l}\text { a The conc } \\
\text { untreated } \\
\text { DIGSA, } \\
\text { percent g } \\
\text { species. }{ }^{c}\end{array}$ & $\begin{array}{l}\text { tion of active ingredi } \\
\text { rols when sprayed p } \\
\text { CG, SETFA, SORBI. } \\
\text { reduction compared } \\
\text { re of } \text { cis and trans. }{ }^{\mathrm{d}} \mathrm{S}\end{array}$ & $\begin{array}{l}\text { provi } \\
\text { gently } \\
\text { ncent } \\
\text { treate } \\
\text { but ut }\end{array}$ & $\begin{array}{l}\text { rage grc } \\
\text { ollowing } \\
\text { active in } \\
\text { when sp } \\
\text { diasterec }\end{array}$ & $\begin{array}{l}\text { duction of } \\
\text { species: A } \\
\text { t that prov } \\
\text { post emerge }\end{array}$ & $\begin{array}{l}\text { compared } \\
\text { Y, AVEF } \\
\text { he indicat } \\
\text { on the list }\end{array}$ \\
\hline
\end{tabular}

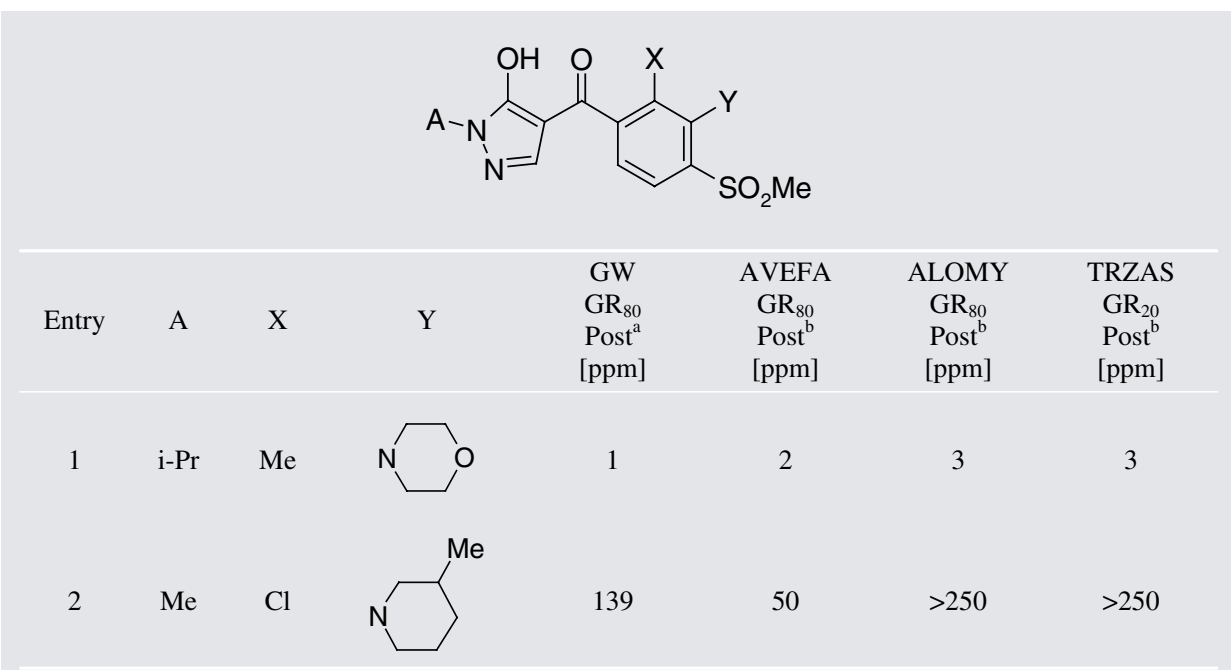

${ }^{a}$ The concentration of active ingredient that provides an average growth reduction of $80 \%$ compared to untreated controls when sprayed post emergently on the following grass species: ALOMY, AVEFA, DIGSA, ECHCG, SETFA, SORBI. ${ }^{\text {b}}$ The concentration of active ingredient that provides the indicated percent growth reduction compared to an untreated control when sprayed post emergently on the listed species. 


\section{Summary}

A practical and general approach to 3-azacyclobenzoylpyrazoles has been developed based on aromatic substitution by amines. The efficiency of analog synthesis was markedly improved by performing the substitution on advanced benzoylpyrazole intermediates. Problems related to the preparation of substituted morpholino analogs were solved by a four-step in situ procedure based on glyoxal cyclization. Unsubstituted or small alkyl substituted morpholino substituents were found to provide the greatest activity on the key cool season grass weeds wild oat and blackgrass. On the other hand, significant wheat selectivity with respect to wild oat was observed with a piperidino moiety if there was a small alkyl group incorporated at $\mathrm{C}(3)$ of that ring.

Received: September 17, 2003

[1] a) D.L. Lee, M.P. Prisbylla, T.H. Cromartie, D.P. Dagarin, S.W. Howard, W.M Provan, M.K. Ellis, T. Fraser, L.C. Mutter, 'The discovery and structural requirements of inhibitors of $p$-hydroxyphenylpyruvate dioxygenase', Weed Sci. 1997, 45, 601; b) K.E. Pallett, J.P. Little, P. Veerasekaran, F. Viviani, 'Inhibition of 4 hydroxyphenylpyruvate dioxygenase: the mode of action of the herbicide RPA 201772 (isoxaflutole)', Pestic. Sci. 1997, 50, 83; c) M.P. Prisbylla, B.C. Onisko, J.M. Shribbs, D.O. Adams, Y. Liu, M.K Ellis, T.T. Hawkes, L.C. Mutter, 'The novel mechanism of action of the herbicidal triketones', Proc. Brighton Crop Prot. Conf.-Weeds 1993, 731; d) A. Schultz, O. Ort, P. Beyer, H. Kleinig, 'SC-0051, a 2 benzoyl-cyclohexane-1,3-dione bleaching herbicide, is a potent inhibitor of the enzyme p-hydroxyphenylpyruvate dioxygenase', FEBS Lett. 1993, 318, 162; e) J. Secor, 'Inhibition of barnyardgrass 4-hydroxyphenylpyruvate dioxygenase by sulcortrione', Plant. Physiol. 1994, 106, 1429; f) E. Fiedler, J. Soll, G. Schultz, 'The formation of homogentisate in the biosynthesis of tocopherol and plastoquinone in spinach chloroplasts', Planta 1982, 155, 511 .

[2] a) J.M. Beraud, J. Claument, A. Montury, 'ICI-A 0051, a new herbicide for the control of annual weeds in maize', Proc. Brighton Crop Prot Conf.-Weeds 1991, 1, 51; b) G. Mitchell, D.W. Bartlett, T.E.M. Fraser, T.R. Hawkes, D.C. Holt, J.K. Townson, R.A. Wichert, 'Mesotrione: a new selective herbicide for use in maize', Pest Manag. Sci. 2001, 57, 120.
[3] a) B.M. Luscombe, K.E. Pallett, P. Loubiere, J.C. Millet Melgarejo, T. E. Vrabel, 'RPA 20772: a novel herbicide for broad leaf and grass weed control in maize and sugar cane', Proc. Brighton Crop Prot. Conf-Weeds 1995, 35; b) K.E. Pallett, S.M. Cramp, J.P. Little, P. Veerasekaran, A. Crudace, A.E. Slater, 'Isoxaflutole: the background to its discovery and the basis of its herbicidal properties', Pest Manag. Sci. 2001, 57, 133.

[4] M. Baba, N. Tanaka, T. Ishi, T. Nawamaki, US 4744815, 1988; b) M. Baba, T Kakuta, N Tanaka, E. Oya, T. Ikai, T. Nawamaki, S. Watanabe, US 4885022, 1989; c) Z. Benko, T. Siddall, G. Garvin, S. Shinkle, 'Bis-alkylsulfonylated benzoylpyrazoles: Synthetic methods for incorporating two alkylsulfonyl groups in a tetrasubstituted aromatic ring', Abstracts of Papers - American Chemical Society 2001, 221st AGRO-075.

[5] a) Experimental details may be found in this reference: Z.L. Benko, J.A. Turner, M.R. Weimer, G.M. Garvin, J.L. Jackson, S.L. Shinkle, J.D. Webster (Dow AgroSciences), US 5824802 1998; b) Z. Benko, S. Shinkle, J. McQuiston, J. Webster, J. Jackson, G. Garvin, J. Turner, M. Ricks, D. Ouse, E. Patterson, M. Weimer, '3Azabenzoylpyrazole herbicides', Abstracts of Papers - American Chemical Society, 2001, 221st AGRO-002.

[6] The lower yields are largely due to the competing formation of the corresponding pyrazolobenzpyran, in which the hydroxypyrazole cyclizes onto the $\mathrm{C}(2)$ of the benzoyl when there is a leaving group present.

[7] Hydroxypiperidines were modified by standard methylation, oxidation and chlorination procedures.

[8] D. Chassonnery, F. Chastrette, M. Chastrette, A. Blanc, G. Mattioda, 'Disproportionation reactions from glyoxal and difunctional basic molecules', Bull. Chim. Soc. Fr. 1994, 131, 188. Other two carbon, dielectrophiles such as methyl 2-bromoacetate, chloroacetaldehyde and glycolaldehyde dimer failed to give a reaction.

[9] The use of dichloromethane as solvent for this reaction was important - no product was obtained in THF. In the examples presented in this paper, the lactols existed entirely in the closed form. Other researchers have found equilibrium mixtures in related systems: a) N.H. Cromwell, K. Tsou, $J$. Am. Chem. Soc. 1949, 71, 993; b) R.E. Lutz, R.H. Jordan, J. Am. Chem. Soc. 1949, 71, 996.

[10] The syntheses of the corresponding oxazolidine, isoxazolidine and 1,4-oxazepine analogs were attempted following literature precedents, but they failed either at the cyclization or nucleophilic aromatic displacement step.

[11] G.G. Gibson, P. Skett, 'Drug Metabolism', Chapman \& Hall, New York, 1994. 